\title{
Jovens, violência e saúde: construção de informações nos processos de mediação e apropriação de conhecimentos ${ }^{1}$
}

DOI: 10.3395/reciis.v3i3.275pt

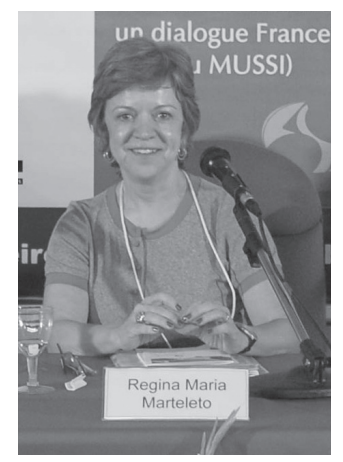

\section{Regina Maria Marteleto}

Instituto de Comunicação e Informação Científica e Tecnológica em Saúde-Fiocruz, Rio de Janeiro, Brasil

rmarteleto@icict.fiocruz.br

\section{Resumo}

Esse é um relato de pesquisa que estuda como os jovens moradores de periferia das grandes cidades, na condição de sujeitos da informação, transformam os sentidos que circulam socialmente em formas discursivas e narrativas - o "terceiro conhecimento" -, revelando as ações de violência física e simbólica do Estado, da mídia, da escola e da sociedade, que concorrem para uma representação negativa de suas identidades. Fazem parte do campo empírico da pesquisa grupos de jovens ligados a projetos sociais de organizações não-governamentais, organismos estatais ou movimentos sociais. Empregam-se os conceitos de mediação e apropriação social de conhecimentos para estudar de que forma eles traduzem, em suas reservas simbólicas, as suas experiências de violência. Apresenta-se um experimento de informação, um fanzine sobre a violência, construído de forma compartilhada no processo da pesquisa, para expressar os impasses e saídas em relação aos contextos e situações de vida desses jovens. A análise interpretativa, realizada com o emprego de instrumentos da metodologia qualitativa, aponta para um impasse simbólico e identitário em relação a uma possível ação informacional sobre os contextos de violência nos quais eles se encontram inseridos.

\section{Palavras-chave}

informação e sociedade; jovens; violência; conhecimento social; fanzine

\section{Introdução}

O principal ponto de interesse comum que reuniu ao longo do tempo os elos entre os grupos de pesquisa da antropologia da informação - campo de pesquisa no qual se insere a pesquisa que se relata neste artigo - e o campo da saúde, é a questão da produção, utilização e distribuição do conhecimento na sociedade. Os focos analíticos e interpretativos das pesquisas orientam-se em direção aos seguintes objetos e questões: a informação no nível local; a informação produzida e utilizada na e para a intervenção social; o interesse pela questão do conhecimento e sua democratização; a visão dos atores sociais e dos usuários dos serviços de saúde e dos sistemas de informação como sujeitos coletivos.

O interesse teórico orienta-se pela articulação entre o conhecimento, a informação e a sociedade. As pesquisas levam em conta o atual contexto sócio-político-econômicocultural, no qual as questões do conhecimento e do acesso 
à informação tomam nova e expressiva relevância no processo de desenvolvimento econômico, no exercício da cidadania, na educação e no trabalho. Em um esforço de evitar uma visão centralizadora, trabalha-se com a idéia de conhecimento associado à ação, acreditando-se que as ações visando a fins de intervenção e de transformação social criam modos de compartilhar as informações e de ampliar as cosmovisões dos indivíduos, promovendo novas formas de compreensão, produção e uso dos conhecimentos. As novas formas de combinar conhecimento teórico e prático, a importância distinta e essencial de cada um deles para uma compreensão mais apropriada de como alcançar os objetivos de mudança e melhoria das condições de vida, é o que denominamos "construção compartilhada do conhecimento".

Para entender empiricamente os processos de apropriação de conhecimentos e de produção de informações emprega-se o conceito operacional "terceiro conhecimento", que nomeia as combinações e as disputas, sempre renováveis e provisórias, entre o conhecimento científico (ou informacional), o conhecimento midiático e as diversas formas de expressão do conhecimento popular (ou prático), o que significa ultrapassar a visão da informação como "estoque" e trabalhar, no nível local, com a idéia de "informação-fluxo", "informação-prática”, "informação-intervenção" ou, para manter o conceito que vem sendo utilizado ao longo do processo das pesquisas, "informação em movimento".

Nesse caminho, a construção do objeto da pesquisa que aqui se apresenta - a representação e expressão informacional dos jovens sobre a violência - demanda uma abordagem interdisciplinar que abarca questões e conceitos das áreas da informação, da saúde e das ciências sociais.

O aumento da violência, que agrava as já precárias condições de vida das populações dos grandes centros urbanos, especialmente os jovens, expostos por uma maior mobilidade pela cidade e vulnerabilidade a atos violentos, é hoje uma das grandes causas de deterioração do quadro da saúde pública no país. E, por se tratar de uma questão de saúde, é também um enorme problema social, porque revela o descompromisso das esferas do Estado e das elites econômicas, políticas e intelectuais do país com a formação, educação e assistência às crianças e aos jovens.

Um pressuposto geral que se formula nas pesquisas da antropologia da informação é de que não existe questão informacional que não seja também (ou antes), uma questão social. Por isso, e para formular problemas informacionais pertinentes, é necessário focalizá-los no contexto das perguntas sociais do seu tempo. Essa assertiva já se encontrava presente no campo de estudos da informação desde Shera (1977), que esboçou, nos anos de 1950, os primeiros contornos de uma epistemologia social que tem em vista a construção de saberes e práticas informacionais que colocam a ciência em diálogo com a sociedade e com outras ordens de conhecimentos com o fim de alimentar as políticas e ações para o desenvolvimento social.
Articulam-se no estudo, em perspectiva interdisciplinar, conceitos e metodologias que nascem do intercruzamento de três campos disciplinares: as ciências sociais, da informação e da saúde. Em outra perspectiva, transdisciplinar, estuda-se o caminho do diálogo - seja pela disputa, dissenso, embate ou aliança - entre o conhecimento científico e o conhecimento de senso comum, na ambientação do que Santos (1995) denomina "comunidades interpretativas", uma reunião de atores da ciência e da sociedade para o debate e a produção de novos conhecimentos de serventia para o desenvolvimento da sociedade e a democratização do acesso e da apropriação das informações.

A partir desse entendimento a pesquisa estudou a narratividade e a expressão informacional dos jovens, representados por grupos envolvidos em projetos de construção de mídias comunitárias das organizações nãogovernamentais Associação Imagem Comunitária (AIC) e Humbiumbi, localizadas em Belo Horizonte, e em ações de intervenção social como o Grupo Maré Jovem, e o Adolescentro da Rocinha, no Rio de Janeiro.

Uma estratégia de aproximação sucessiva do objeto de estudo e de diálogo e convívio com os jovens foram delineados, buscando-se os meios de incorporar, gradativamente, diferentes perspectivas teóricas e metodológicas para a construção da pesquisa. Criando meios de representar, em suporte informacional, os modos de articulação dos conhecimentos - científico, massivo, popular - para estudar os processos de formação, relativização e desintegração de identidade coletiva dos jovens e seus grupos locais, a partir da representação social criada pela informação produzida pelos meios de comunicação de massa e pelo poder público, foi construído um experimento-dispositivo de informação sobre o tema violência - o Zine Violento. A opção pelo formato do fanzine deu-se por se tratar de uma forma de escrita e de informação que parece refletir os modos de interação e comunicação entre os jovens nos dias de hoje, tanto em meio impresso quanto eletrônico ou digital.

\section{Jovens, saúde e violência: uma questão de informação?}

A violência social é um tema que vem ocupando o imaginário e a sobrevida da sociedade, e tornou-se um objeto de estudo do campo da saúde, além das ciências sociais. No caso da sociedade brasileira, é uma questão desafiadora devido aos problemas estruturais que favorecem o crescimento e a exacerbação de conflitos violentos. Além disso, a violência tem um enorme impacto sobre a saúde da população e sobre os serviços de saúde.

No Brasil, o quadro da violência tem certas peculiaridades, embora conserve dois traços comuns em relação a outros países: (a) é o Estado que detém o monopólio da violência; (b) são os jovens e os homens os que morrem mais, vítimas de violência (MINAYO, 1997). No entanto, segundo a autora, a incidência de crimes no país "é crescente e insidiosa", lembrando que alguns estudiosos buscam as causas dessa situação no narcotráfico crescente nas cidades, enquanto outros buscam razões mais pro- 
fundas nas nossas estruturas sócio-políticas e culturais, apontando as raízes autoritárias da sociedade brasileira e a constante violação dos direitos humanos como possíveis responsáveis pela situação endêmica e o crescimento da violência social. Outros autores introduzem nessas reflexões a categoria de "exclusão moral", segundo a qual o pressuposto formal da inclusão de todos como sujeitos de direitos mascara a existência de grupos à margem da sociedade, pois tais grupos são percebidos no imaginário popular como indignos dos benefícios que recebem, e ônus para os que se julgam cidadãos de fato.

Desse modo, é importante incorporar outros referenciais na análise das tendências de crescimento dos homicídios e de outros tipos de criminalidade no Brasil, dentre eles a dificuldade de grande parte das camadas populares de reconhecerem os direitos humanos como sendo seus próprios direitos. Essa dificuldade, associada à cultura arraigada da aceitação de práticas ilegais dos agentes do Estado contra os grupos considerados marginais, tem como conseqüência o embotamento dos mecanismos de autocontrole moral e a incorporação do sentimento de exclusão. A não-universalização da lei gera um círculo vicioso e perverso no país, segundo o qual a não-violência só é defendida pelos que têm seus direitos sociais e econômicos garantidos (MINAYO, 1997).

Nesse quadro, os jovens pobres das periferias das grandes cidades sofrem, além da violência física dos aparatos policiais do Estado e das próprias situações violentas do seu cotidiano, outro nível de violência, - a simbólica -, gerada pelas informações e imagens da mídia e reproduzidas em diferentes espaços e instituições sociais, as quais estigmatizam suas identidades, ao associarem esses jovens com crimes, vandalismos e agressões.

Dayrell, ao refletir sobre os jovens das classes populares como sujeitos sociais, afirma que considerar os jovens por essa ótica não se reduz a uma opção teórica, mas a uma postura metodológica e ética:

ver e lidar com o jovem como sujeito, capaz de refletir, de ter suas próprias posições e ações, é uma aprendizagem que exige um esforço de auto-reflexão, distanciamento e autocrítica. A dificuldade ainda é maior quando o 'outro' é 'jovem, preto e pobre’, essa tríade que acompanha muitos dos jovens como uma maldição (DAYRELL, 2003, p.44).

Nesse contexto, relacionar a questão da violência com a saúde e a juventude, por uma ótica informacional, exige uma compreensão da problemática da informação no campo da saúde, uma vez que os estudos em comunicação, informação e saúde, apesar das críticas neles incorporadas sobre o modelo difusionista e linear emissor-receptor que prevalece nos modelos aplicados nesse campo, ainda se orientam muitas vezes por uma lógica de "oferta informacional".

Uma visão elitista e unilateral da ciência, somada à própria concepção de saúde como um estado a ser atingido pela população em geral, tem orientado, ao longo do tempo, os programas oficiais de educação, informação e comunicação em saúde. No entanto, como observa Oliveira, não se trata de conscientizar, educar, despertar ou sensibilizar a população, nem de apenas identificar carências, “...mas de valorizar os sujeitos naquilo que têm de melhor, sua história, seu tempo - a sua capacidade de criação" (OLIVEIRA, 2003b, p.37). Ou ainda, como afirma Samaja (1998), as expectativas em termos de uma vida saudável, tal como são definidas pelas pessoas de modo espontâneo, guardam sempre relação com os processos sociais vivenciados cotidianamente, e constituem pressupostos da configuração de sentidos ou narrativas construídas para dar conta das rupturas, bloqueios ou perturbações existentes.

Assim, estudar a relação jovem-violência-saúde por uma ótica informacional exige que se adote uma leitura local e cultural dos processos de subjetivação e de construção de sentidos em torno do mundo vivido dos jovens sem, no entanto, perder de vista os elos que o local mantém com o quadro macro-estrutural da sociedade.

\section{Informação e conhecimento: mediações e apropriações}

A idéia de "terceiro conhecimento" está relacionada à ação social dos sujeitos e está ligada, de um lado, aos meios de produção, apropriação e disseminação de informações e, de outro, aos usos, que compõem sua faceta mais indeterminada e instável e que, portanto, abrem brechas para novas mediações, sentidos e realidades.

Estudar a produção do "terceiro conhecimento" a partir de práticas e vivências sociais implica sistematizar as experiências narradas pelos sujeitos, ou registradas discursivamente em documentos ou falas autorizadas. O discurso - ou formações discursivas - como entende Foucault (2004), está sujeito a mecanismos internos e externos que controlam sua veracidade ("vontade de verdade”), sua oposição em relação a formas narrativas de saber (a oposição entre razão e loucura), os atestados de autoria, os comentários que se fazem, de forma autorizada, os discursos, e que mantêm a sua perenidade e autoridade.

A narrativa, seu contraponto, expressa o tempo sem pressa do mundo vivido, a memória social, a interação, as utopias, como analisa Benjamin (1993). Seu termo oposto é a informação, que religa na modernidade os sentidos fragmentados pela razão científica, tecnologias e midiatizações da cultura.

Discurso e narrativa são dimensões da linguagem importantes de serem consideradas quando se empregam as noções de mediação e de compartilhamento e apropriação, para o avanço da compreensão do "terceiro conhecimento" e da sua construção nos ambientes da cultura.

Mediação é uma construção teórica destinada a refletir sobre as práticas e os dispositivos que compõem os arranjos de sentidos e formas comunicacionais e informacionais nas sociedades atuais, sem perder de vista os elos que, tanto os conteúdos quanto os suportes e os acervos, mantêm com a tradição cultural. É um termo que, segundo Gellerau (2006), pode ser entendido sob dois prismas: o de "relação com um sistema" (ex. a mediação social) ou o de "construção de sentido" (o processo 
interpretativo). Seja numa ou noutra acepção, a mediação implica sempre em acompanhamento, controle e negociação por um "terceiro", enquanto o sujeito que se beneficia de um processo de mediação é levado a aprofundar o seu próprio ponto de vista e a descobrir outros. Sob o ângulo da construção de sentidos, a noção se fundamenta no fato de que os sentidos não são imanentes aos objetos, mas são construídos processualmente por sujeitos interpretantes, apoiados em linguagens e dispositivos.

Nos estudos da informação e da comunicação, o modelo da mediação resulta de uma evolução necessária em relação a dois outros modelos: "o da transmissão de informações, apoiado no par emissor-receptor (...) e o da interação, onde a comunicação é definida como a resultante das interações entre os sujeitos sociais" (BORDEAUX, 2003, p.5). Essa evolução emerge de um movimento mais geral que dá uma importância maior ao papel dos públicos e usuários e à democratização cultural, assim como aos dispositivos e às redes.

Hennion (1993), ao estudar o conceito de mediações, pretende realizar uma "sociologia das mediações" para criar uma outra via de entendimento que escape da razão dualista "indivíduo-sociedade", que paira nas ciências sociais desde Durkheim. O termo mediação "designa o lugar de interrogação, apontando como problemática a articulação entre essas duas maneiras duais de interrogar o mundo social" (HENNION, 1993, p.223). Para o autor, a atribuição das causas não é uma operação teórica decidida pelo pesquisador, mas o trabalho prático constante dos atores que ele observa, e é preciso fazer dessas atribuições o próprio objeto da pesquisa. Entre as vantagens teórico-metodológicas do emprego da idéia de mediações enumeradas por Hennion, ele observa que a palavra designa uma operação, e não operadores:

ela não obriga a fazer uma separação de princípio entre instrumentos, e permite circular sem solução de continuidade dos humanos às coisas, passando por sujeitos ou objetos, instrumentos, sistemas, linguagens, instituições; [...] ela reenvia ao mesmo tempo a uma longa série de personagens-chave, aos papéis complementares e concorrentes [...]; e a uma lista [...] de dispositivos materiais ou institucionais encaixados, mais ou menos fixos nas coisas... (HENNION, 1993, p.224-5).

A noção de mediação reinaugura questões que sempre estiveram presentes no campo de estudos da cultura, informação, comunicação e conhecimento: ao recusar a transparência, ela mostra o quanto os dispositivos de comunicação/informação, a estruturação dos lugares, textos, espaços e acervos influenciam as interpretações e produzem objetos mistos e portadores de sentidos. Como ressalta Davallon,

o que o modelo da mediação faz aparecer, é menos os elementos (a informação, os sujeitos sociais, a relação, etc) e mais a articulação desses elementos num dispositivo singular (o texto, a midia, a cultura). No fundo, é essa articulação que aparece como o terceiro (DAVALLON, 2003, p.54-5, grifo nosso).

Portanto, a idéia de mediação permite que se revelem novos dispositivos de configuração e apropriação de informações, como gêneros em mutação ou novos meios de comunicação, não de massa, mas, ao contrário, sociais, porque, construídos coletivamente, mostram não somente imagens, mas objetos e sujeitos verdadeiros.

O conceito de mediação, ao privilegiar uma análise relacional do conhecimento e das informações, faz com que, ao se propor um texto organizador e divulgador do discurso elaborado pelos atores institucionais do campo da saúde, a ser apresentando ou veiculado em diferentes espaços e mídias, leve-se em conta que existe uma negociação entre as propriedades do discurso proposto e as estratégias de apropriação dos sujeitos sociais.

Uma via complementar ao conceito de mediações é a da apropriação e compartilhamento dos conhecimentos. Jeanneret (2004) observa que essa idéia, desde os anos 1970, foi desenvolvida numa perspectiva difusionista do conhecimento científico. No entanto, hoje ela assume as seguintes características: a) não se trata mais da ciência enquanto tal; b) as formas de discursos estudadas são muito diversas, longe do modelo unificador da vulgarização; c) a abordagem pragmática da informação e da comunicação torna-se predominante em relação à abordagem crítico-denuncista dos anos de 1970. O "como fazer" toma o lugar do "para que".

O autor considera que essa abordagem pragmática foi construída e firmou-se por meio de estudos que retiram das noções de mídia e saber a sua pretensão de exterioridade mútua, colocando em evidência "as condições de enunciação de diferentes palavras sobre os saberes, longe da representação de um circuito no qual os saberes preexistiriam à sua difusão" (JEANNERET, 2004, p.20). Logo, pensa-se mais em um "compartilhamento entre os saberes" do que em um "compartilhamento de saberes", que os estudos das ciências da comunicação e da informação vêm se dedicando a investigar.

\section{Universo empírico e metodologia}

Os jovens sujeitos da pesquisa estão integrados em ações e projetos de intervenção social na Associação Imagem Comunitária (AIC) e na Humbiumbi, em Belo Horizonte. No Rio de Janeiro, no Adolescentro Paulo Freire e no Grupo Maré Jovem.

A AIC é uma organização não-governamental (ONG) que desenvolve estratégias para inclusão de diferentes universos sociais e culturais no processo de criação e uso de mídias de acesso público. Seus fundadores e coordenadores são jovens egressos ou ainda estudantes de universidades públicas. Dentre os projetos que conduz, destaca-se o Rede Jovem de Cidadania, rede de comunicação comunitária que envolve centenas de adolescentes e jovens, provenientes de todas as regiões de Belo Horizonte. Por meio da produção de dispositivos e ferramentas de comunicação comunitária, promove o protagonismo juvenil, a mobilização e consolidação de identidade, buscando a construção de uma imagem positiva do jovem (http://www.aic.org.br).

A Humbiumbi, também uma ONG, desenvolve projetos que aliam cultura, juventude e cidadania, realizando projetos de comunicação, artes, saúde, acompanhamento 
familiar e participação comunitária. Realiza, ainda, oficinas de capacitação para professores e alunos em escolas públicas, programas de inclusão digital, crítica da mídia e produção de material educativo para escolas, grupos comunitários e outras entidades. Além disso, a instituição busca envolver diversos segmentos da comunidade e fazer do seu Centro Cultural um espaço de convivência e de expressão genuína da população periférica da região onde atua (http://www.humbiumbi.org.br).

O Adolescentro Paulo Freire, ligado à Secretaria Municipal de Saúde e Defesa Civil do Rio de Janeiro, atende a população jovem das comunidades da Rocinha, Vidigal e Vila Canoas. É um espaço de promoção e atenção à saúde, onde adolescentes e jovens se envolvem diretamente no planejamento e execução das atividades, contribuindo para qualificar o atendimento e melhorar a qualidade de vida em suas comunidades. (http://www. saude.rio.rj.gov.br/adolescente).

A Rede Maré Jovem, criada por jovens moradores das comunidades do complexo da Maré, procura construir uma cultura do encontro entre os moradores, sobretudo os jovens, diante dos desafios e das barreiras impostos por orientações que limitam o ir e vir da juventude, (como os do banditismo organizado e sua repressão) e quanto às definições presentes nos discursos da mídia, do Estado e de segmentos sociais que tratam os jovens como um problema. Os membros da Rede Maré Jovem formam um coletivo que busca contribuir na melhoria da qualidade de vida - presente e futura - da juventude local (ARAÚJO et al., 2009)

Um pressuposto geral sustenta as atividades desses grupos e entidades: a apropriação dos conhecimentos implícitos nos processos de produção de informações tem potencial para criar possibilidades de construção de novas identidades individuais e coletivas, bem como de um redimensionamento da relação dos jovens com o espaço público das mídias e com os processos coletivos de emancipação e conquista da cidadania. Esse pressuposto coloca essas organizações em consonância com a orientação teórico-metodológica dessa pesquisa, na medida em que apóiam o desenvolvimento de mídias voltadas para a pluralidade discursiva e narrativa, trazendo intrínseca, em seus projetos e métodos a apropriação e construção compartilhada do conhecimento.

Quanto aos instrumentos metodológicos, priorizouse o emprego de modalidades participativas e interativas, como a realização de oficinas e entrevistas com grupos focais, cujas temáticas reuniram as questões da saúde e da violência, pelo prisma das vivências e representações dos jovens sobre o espaço da cidade, a família, a mídia, a escola, a polícia, os grupos de convívio e a participação nas atividades ligadas aos projetos sociais nos quais se encontram inseridos. Outros instrumentos complementares foram empregados, como a análise temática de conteúdos de páginas web e de uma amostragem de boletins, jornais, webzines e vídeos produzidos nas atividades das entidades com os jovens. Além desses procedimentos, foram feitas observações diretas de oficinas de replicação de construção de mídias comunitárias feitas pelos jovens em escolas da rede pública, o que permitiu a formação de um amplo e integrado banco de dados empíricos, que serviu de base tanto para as explorações teórico-metodológicas da pesquisa como um todo, quanto para o fornecimento de material textual para os fanzines.

A construção das categorias operacionais-empíricas, destinadas à análise interpretativa do universo informacional dos jovens sobre os seus contextos violentos de vida, levou em conta os seguintes pontos, que orientaram os roteiros temáticos dos instrumentos: a) o significado e as experiências vividas e/ou presenciadas de violência; b) a violência no cotidiano; c) canais e fontes de informação sobre violência; d) responsabilidades em relação ao problema; e) agentes da violência e expectativas em relação ao futuro.

O pressuposto teórico-metodológico que orientou a análise interpretativa baseou-se na seguinte equação, representada na Figura 1: a informação, para funcionar como instrumento de ação sobre a realidade, necessita de dois elementos - uma expressão cognitiva, resultado de um processo de apropriação de conhecimentos, e uma produção de sentidos, relacionada aos universos vivenciais e simbólicos de leitura de significados. Dito de outra forma, carece de compreensão cognitiva, interpretação simbólica e ambientação cultural.

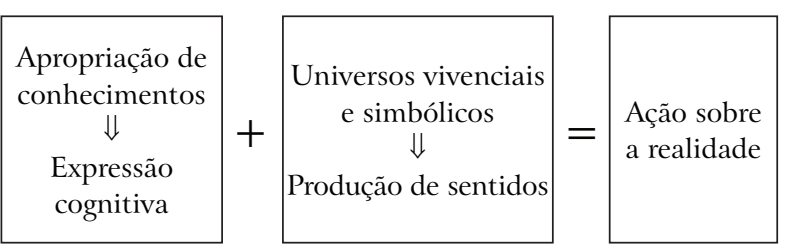

Figura 1 - Equação informacional.

Essa equação informacional norteou a construção, de forma compartilhada entre os jovens e a equipe de pesquisa, de uma série de 3 fanzines sobre a violência - o "Zine Violento".

\section{Fanzines e o zine violento}

Os formatos e intenções dos fanzines os aproximam dos produtos da imprensa popular e outros tipos de publicações, como os folhetos de cordel ou os almanaques, por exemplo (MAGALHÃES, 2002). No formato que têm hoje, teriam surgido nos Estados Unidos, na década de 1930 do século XX. São inúmeros, não têm renovação e periodicidade regulares, abrangem variados assuntos e assumem as formas mais experimentais, mas têm pelo menos uma característica em comum: são veículos de opinião "extra-oficial", entendendo-se por "extra-oficial" aquilo que não está comprometido com empresas, organizações, governos ou instituições (LIMA, 2007). Como veículo de comunicação, alastrou-se pelo mundo inteiro, expressando idéias e informações sobre determinado assunto, de forma livre e independente, graças ao seu baixo custo, pois geralmente é rodado em fotocopiadoras (xerox) e divulgado através dos correios 
ou, como atualmente, pela Internet (os e-zines). Devido a essas características, os jovens são os principais autores e participantes na produção, leitura e apropriação desses meios.

O Zine Violento - e o nome escolhido já procura demonstrar a intenção de diálogo com o linguajar próprio dos jovens, pois ‘violento' é usado por eles como sinônimo de bonito, interessante - foi desenvolvido como um experimento informacional em formato impresso, um modelo de comunicação aberto, alternativo à comunicação dos panfletos descartáveis e aos manuais prescritivos oficiais das campanhas de saúde e de segurança pública
(Figura 2). Os conteúdos procuram mostrar as visões e contradições presentes no imaginário dos jovens por meio de suas próprias vozes. A preocupação principal não é com uma coerência única das falas, mas com o protagonismo múltiplo dos jovens sujeitos da pesquisa. Nesse sentido, foi feita uma análise do vasto material textual produzido pelos recursos metodológicos com que se procurou perceber as vozes dos grupos de jovens e o que elas narravam sobre violência, de forma direta ou indireta. Sendo assim, não só as falas, mas também os silêncios entre palavras, os gestos, os risos, os olhares fizeram parte do que se escutava por meio de suas vozes.
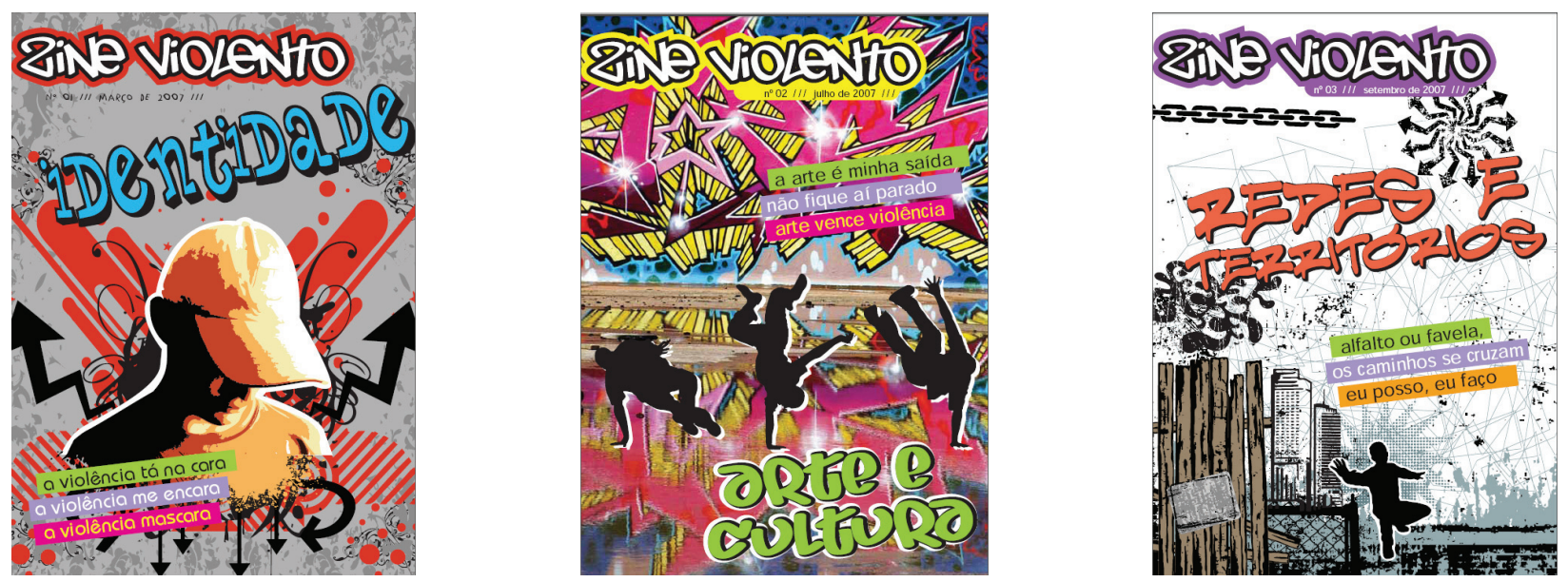

Figura 2 - Capas dos "Zine Violento".

O primeiro número do fanzine aborda a conscientização sobre o ato de ler como instrumental para compreensão e interferência sobre o mundo e, portanto, como possibilidade de construção de identidades e de transformação de realidades; o segundo fanzine intensifica a questão da conscientização sobre os modos de singularização, potencializados pelo processo de criação estética com o qual já convivem, muitas vezes, força expressiva de suas experiências de viver a vida: o rap, o grafite, as narrativas de vídeos, teatros, rádios etc.; o terceiro aviva a pergunta sobre a interferência possível para modificação das políticas públicas, tornando-as, com o reforço das redes sociais construídas, um espaço a ocupar a fim de transformá-lo em construção própria, uma territorialidade.

Em cada um dos números do "Zine Violento" buscou-se roteirizar o texto pelas falas dos jovens da pesquisa, em entrecruzamento simbólico e hipertextual com matérias de mídia, músicas, ilustrações, dados e reflexões acadêmicas sobre a situação da violência com e entre os jovens, para configurar sentidos e interpretações sobre o seu mundo vivido e a incidência da violência.

\section{Resultados: jovens, violência e reserva simbólica}

Os jovens vivenciam e expressam um duplo sentido em relação à violência no seu cotidiano, associado às suas condições de sujeitos sociais excluídos dos direitos de cidadania e identidade social. Uma primeira leitura está relacionada à violência física experimentada nos lugares públicos, praticada pela polícia e aparatos de repressão do Estado, pelo banditismo e por outros jovens, ou nos espaços privados, como a casa e a família, ou institucionais, como a escola. Outra percepção fala da violência simbólica, que formata suas identidades como agressivas e criminosas. Essa última é uma forma de violência que está inscrita nas mensagens e imagens veiculadas pelas mídias e reproduzidas no imaginário da sociedade e em suas instituições, indicando uma primeira leitura, feita pelos jovens, sobre o efeito informacional da violência sobre as suas condições de vida.

Em geral, relatam múltiplas situações cotidianas de violência vivenciadas nos espaços públicos e privados, envolvendo a si próprios ou alguém do seu círculo familiar ou de amizade. No público, pensam que se trata de uma "violência visual", associada ao preconceito, por serem "pobres, pretos e moradores de favelas." $\mathrm{Na}$ escola, por conta do autoritarismo e preconceito de alguns professores e as agressões dos colegas. E na família, vivenciam atos violentos de pais ou padrastos alcoolizados e/ou agressivos e devidos ao convívio com vários familiares num mesmo espaço.

Pensam que a programação da televisão, principalmente, é uma fonte de informação que estimula as 
atitudes violentas em crianças e jovens, que são interiorizadas e reproduzidas por eles na família, no convívio com os colegas e na escola. Como se trata de jovens inseridos em projetos sociais de produção compartilhada de mídias comunitárias, consideram que tanto os jornais e as rádios quanto a Internet veiculam informações que, tanto estimulam quanto orientam as suas visões sobre o contexto e a dimensão da violência na sociedade.

Quando expressam as suas opiniões sobre quem são os agentes da violência, surge em primeiro lugar a polícia e a sua ação preconceituosa e agressiva com os jovens nas comunidades onde vivem ou nos espaços públicos ou de lazer. Em segundo, os familiares, principalmente padrastos, pais ou irmãos. Em seguida, professores e colegas de escola. "Violência gera violência", dizem para mostrar que os atos violentos ocorrem em cadeia, quando acontece uma primeira agressão, ou seja, é quase sempre uma (re)ação.

Sobre a responsabilidade e as medidas necessárias em relação ao quadro de violência social, acreditam que o governo deveria tomar medidas e elaborar políticas públicas, uma vez que a única face do Estado que está presente em suas vivências é a da ação repressora da polícia. Mas também acreditam que eles próprios têm uma parcela de responsabilidade na violência entre e contra os jovens.

O pressuposto teórico-metodológico da pesquisa expressa uma equação informacional, segundo a qual a apropriação de conhecimentos resulta em expressão cognitiva e a capacidade de interpretação de significados dos universos vivenciais e simbólicos resulta numa produção de sentidos para a ação sobre a realidade. Os dados parecem mostrar que essa equação completa-se parcialmente, uma vez que existe uma apropriação de conhecimentos pelos jovens, nas mediações técnicas e simbólicas dos dispositivos comunicacionais e informacionais que produzem nos projetos sociais em que participam. Por outro lado, a produção de sentidos para ação sobre a realidade, dependeria de elementos complementares a um efeito informacional para a transformação da realidade dos jovens, que se relaciona com as suas condições sócio-econômicas e educacionais. Que poder ou efeito teriam as informações produzidas nos processos de mediação e apropriação para alterar as condições de vida dos jovens?

Os procedimentos de apropriação e compartilhamento de conhecimentos, e as mediações que produzem sentidos, ainda que não resultem em ações imediatas de transformação social para os jovens, parecem ocupá-los com ações de afirmação de identidade e consciência de direitos que concorreriam para a formação de uma reserva simbólica capaz de, em diferentes momentos, orientar os seus sentidos e ações de intervenção social.

\section{Conclusões}

$\mathrm{Na}$ área de saúde, é empregada a expressão "sofrimento difuso" para se referir a um estado de adoecimento das pessoas, decorrentes das condições de pobreza e do contexto violento em que vivem. São sintomas físicos, mas que têm origem em sentimentos de medo, desesperança e abandono, que trazem conseqüências somáticas, como dores, depressão, estados de ansiedade (OLIVEIRA, 2003a).

O sofrimento difuso está portanto associado a situações sociais, como as que são vivenciadas pelos jovens - sujeitos da pesquisa - e relatadas em suas falas. No entanto, neles não se manifestam sintomas físicos, mas uma espécie de "impasse simbólico e identitário", por não reconhecerem como seus, os direitos humanos e sociais, o que parece gerar sentimentos de exclusão e de falta de auto-controle moral.

Como age a informação nesse contexto? Qual a sua serventia e usos possíveis?

A informação, conjugada com os demais conceitos aqui tratados enquanto processos simbólicos, pode configurar-se como território de (re)significação para os jovens, na medida em que, servindo-lhes tanto como possibilidade de apropriação, mediação e produção, quanto de compartilhamento de saberes, oportuniza a constituição de singularidades que, articuladas ao contexto, podem ter serventia para a ação social, ainda que não de forma imediata. Pois, para que aconteça conhecimento, são necessários os saberes já apropriados pelo receptor: quem vai procurar a informação já teria alguma espécie de informação sobre ela.

Assim se constrói nos jovens uma reserva simbólica que, abrindo cada vez novos sentidos para a leitura das suas vidas e experiências, desencadeia processos de reapropriação da informação e, conseqüentemente, do conhecimento, a fim de compreendê-los não mais como algo dado, mas, sim, como construção.

Afinal, os procedimentos de construção de experimentos de mídias comunitárias, realizados pelos jovens, com a participação e coordenação de outros jovens instrutores e animadores, acontecem também porque esses últimos fizeram uma ruptura com o modo como o conhecimento é produzido e disseminado na universidade. Esses processos de construção compartilhada e de apropriação de conhecimentos fazem pensar que, tanto as informações, quanto os sentidos que elas transportam, são historicamente elaborados, têm autorias que são datadas e contextualizadas.

O olhar jovem pode passar a ser outro, deslocar-se: em lugar de se fixar sobre os objetos em si, principalmente os objetos simbólicos, olhar para as suas próprias práticas de sujeitos que se apropriam dos objetos que circulam para construir significados. Olhar que não está interessado em somente descrever, mas, sim, em inter-relacionar, construir junto, compartilhar.

O nosso compromisso, enquanto pesquisadores, é com a construção de um instrumento informacional compartilhado, com autorias, vozes e discursos múltiplos, e não de um manual portador de informações prescritivas e descartáveis, com uma concepção transmissional de informações. Ao contrário, o Zine Violento quer ser um dispositivo informacional que se caracteriza pela comunicação aberta, com protagonismo múltiplo e apelo à solidariedade, em detrimento da imagem negativa e 
estereotipada que geralmente se constrói sobre os jovens e a violência . Estamos convictos que essa forma comunicacional e informacional terá mais eficácia do que a culpabilização e a voz única das prescrições tradicionalmente adotadas pela propaganda oficial e pelas ações agressivas e violentas dos aparatos de repressão do Estado.

\section{Notas}

1. O artigo apresenta resultados do projeto integrado de pesquisa Espaço, Tempo, Discurso e Narrativa: construção do conhecimento e representação informacional nas práticas e movimentos sociais no campo da saúde, financiado pelo $\mathrm{CNPq}$, realizado no período de agosto/2003 a fevereiro/2007.

\section{Referências bibliográficas}

ARAUJO, J. W. G., SILVA, S. J. A., SILVA, Eliana S. Associativismo e redes sociais na Maré: do mutirão à cultura do encontro. In: MARTELETO, R. M. STOTZ, E. N. (Org.). Informação, saúde e redes sociais: diálogos de conhecimentos nas comunidades da Maré. Rio de Janeiro: Ed. Fiocruz, Belo Horizonte: Ed. UFMG, 2009, p. 123-138

BENJAMIN, W. Magia e técnica, arte e política: ensaios sobre literatura e história da cultura. (Obras escolhidas, vol.1) São Paulo: Editora Brasiliense, 1993.

BORDEAUX, M. C. La médiation culturelle dans les arts de la scène. Thèse de Doctorat en Sciences de l'Information et de la Communication, Université d'Avignon, 2003.

DAVALLON, J. La médiation ou la communication en procès? Médiation \& Information (MEI), Paris: L'Harmattan, n.19, p.39-59, 2003.

DAYRELL, J. O jovem como sujeito social. Revista Brasileira de Educação, n.24, p.40-52, set/out/nov/dez, 2003.

FOUCAULT, M. A ordem do discurso. São Paulo: Loyola, 2004.

GELLEREAU, M. Pratiques culturelles et médiation. In: OLIVESI, S. Sciences de l'Information et de la Communication: objets, savoirs, discipline. Grenoble: Presses Universitaires de Grenoble, 2006, p. 27-42.
HENNION, A. La passion musicale. Une sociologie de la médiation. Paris: A.M. Métailié, 1993.

JEANNERET, Y. Le partage des savoirs entre métamorphose des médias et poétique des discours. In: METZGER, J-P. (org.). Médiation et répresentation des savoirs. Paris: L'Harmattan, 2004, p. 15-32.

LIMA, L. Fanzine: rotulando o in-rotulável. In: MOOD: pulse e pense. Disponível em: <http://www.mood.com. br/3a0 l/zine.asp>. Acesso em: 6 jul. 2007.

MAGALHÃES, H. Fanzine: do mimeógrafo à editoração eletrônica. Conceitos, Jul./Dez., 2002, p.143-148.

MARTELETO, R. M.; STOTZ, E. N. Informação, saúde e redes sociais: diálogos de conhecimentos nas comunidades da Maré. Rio de Janeiro: Ed. Fiocruz, Belo Horizonte: Ed. UFMG, 2009

MINAYO, M. C. de S. Violência, direitos humanos e saúde. In: CANESQUI, A. M. (Org). Ciências Sociais e Saúde. São Paulo: Hucitec/Abrasco, 1997, p.247-60.

OLIVEIRA, R. M. de. Pistas para entender a crise na relação entre técnicos e classes populares: uma conversa com Victor V. Valla. Cadernos de Saúde Pública, Rio de Janeiro, v. 19, n.4, Jul./Ago., 2003a.

OLIVEIRA, R. M. de. A construção do conhecimento nas práticas de educação em saúde: repensando a relação entre profissionais dos serviços e a população. Perspectivas em Ciência da Informação, Belo Horizonte, v.8, n.1, jan./ jun, 2003b.

SAMAJA, J. Epistemologia e epidemiologia. In: ALMEIDA FILHO et al. (Org.). Teoria epidemiológica hoje: fundamentos, interfaces, tendências. Rio de Janeiro: Fiocruz/ Abrasco, 1998.

SANTOS, B. de S. Pela mão de Alice: o social e o político na pós-modernidade. São Paulo: Cortez, 1995.

SHERA, J. Epistemologia geral, semântica geral e biblioteconomia. Ciência da Informação, Brasília: v.6, n.1, p.9-12, 1977.

\section{Sobre o autor}

\section{Regina Maria Marteleto}

Regina Maria Marteleto é doutora em Comunicação e Cultura (ECO/UFRJ), atua no Laboratório de Estudos em Comunicação e Saúde - Laces//cict/Fiocruz e é pesquisadora do CNPq. Responsável, no Brasil, pela coordenação científica da Rede MUSSI-Rede Franco-Brasileira de Pesquisadores em Mediações e Usos Sociais de Saberes e Informação. Coordena o Grupo de Pesquisa Antropologia da Informação-Antropoinfo. Suas áreas de interesse são cultura e informação; conhecimento, informação e sociedade; informação e saúde; mediações informacionais em redes e movimentos sociais; sujeito, leituras e linguagens de informação na contemporaneidade; teoria, epistemologia e interdisciplinaridade nos estudos da informação. 